\title{
The potential of micromorphology for interpreting sedimentation processes in wetland sites: a case study of a Late Bronze-early Iron Age lakeshore settlement at Lake Luokesa (Lithuania)
}

\author{
Kristin Ismail-Meyer
}

Received: 18 December 2012/ Accepted: 7 April 2014/Published online: 1 May 2014

(C) Springer-Verlag Berlin Heidelberg 2014

\begin{abstract}
Lake Luokesa lies in the eastern part of Lithuania and is part of a region of lakes formed by the Scandinavian ice-sheet and its melt waters during the last glaciation. During the Late Bronze-Early Iron Age transition, between 625 and 535 cal BC, a lakeside settlement with an onshore palisade was built on the platform of a carbonate bank. A total of five profiles, each comprising an organic occupation layer and lake sediments at its bottom and top, were examined micromorphologically. In this paper, natural and anthropogenic processes that led to the formation of the individual layers are presented; their possible origins are reconstructed and then discussed and compared to lakeside settlements of the circum-alpine region. This includes the emergence of lake marl, accumulation of organic layers in the settlement area as well as their decomposition, erosion and trampling features and inwash of sand through runoff from the hinterland. Due to the accumulation of the up to $60 \mathrm{~cm}$ thick culture layers in waterlogged environments, indications of seasonal deposition cycles could be identified.
\end{abstract}

Keywords Site formation processes - Seasonality · Human impact · Trampling · Erosion · Geoarchaeology

Communicated by M. Latałowa.

Electronic supplementary material The online version of this article (doi:10.1007/s00334-014-0459-x) contains supplementary material, which is available to authorized users.

K. Ismail-Meyer $(\bowtie)$

Department of Environmental Sciences, Integrative Prehistory

and Archaeological Science (IPAS), University of Basel,

Spalenring 145, 4055 Basel, Switzerland

e-mail: kristin.meyer@unibas.ch

\section{Introduction}

During the Neolithic and Bronze Age in Central Europe and in the Baltic area even until the Iron Age, people settled on lake shores and built up agricultural and pastoral communities there. Some researchers have shown that platforms were exposed due to fluctuations of the lake water levels during periods of low levels (Magny 2004; Menotti et al. 2005). The unique aspect of lakeside settlements is that a large part of the material brought into the littoral zone by peoples and their domestic animals is well-preserved (Menotti 2012). This is due to a permanently moist environment; weathering and soil formation processes that normally lead to the degradation of organic matter barely took place in these situations. However, in lakeside settlements floods are a limiting factor that can lead to reworking, relocation and erosion of deposits (Ismail-Meyer and Rentzel 2004; Huber and Ismail-Meyer 2012). At the Late BronzeEarly Iron Age (LBA-EIA) site Lake Luokesa 1 (L1), beside the archaeological investigation, botanical macro remains, pollen, dendrochronological and micromorphological analyses were done contemporaneously, in an interdisciplinary way (Pranckénaitè 2014; Pollmann 2014a; Heitz-Weniger 2014; Bleicher 2014). This contribution will give an overview of the micromorphological results from the site.

Micromorphological analyses allow the characterization of natural and anthropogenic sediments, which in turn makes possible the evaluation of the site formation processes and the environment in which the deposits were formed. This method of analysis originally evolved from the study of soil, where the practice of casting soil samples in resin and then examining them microscopically has been used since the 1950s (Babel 1975). This technique has been applied to deposits from archaeological sites since the 1970s (Goldberg and Macphail 2006). Since the early 1990s, 
Fig. 1 Map of Lithuania with lakes, wetlands and rivers marked; the site (star) lies near the city of Moletai and is part of a lake region shown in detail on the left hand side-Lake Luokesa with the site L1 (map by E. Pranckènaitè, modified)

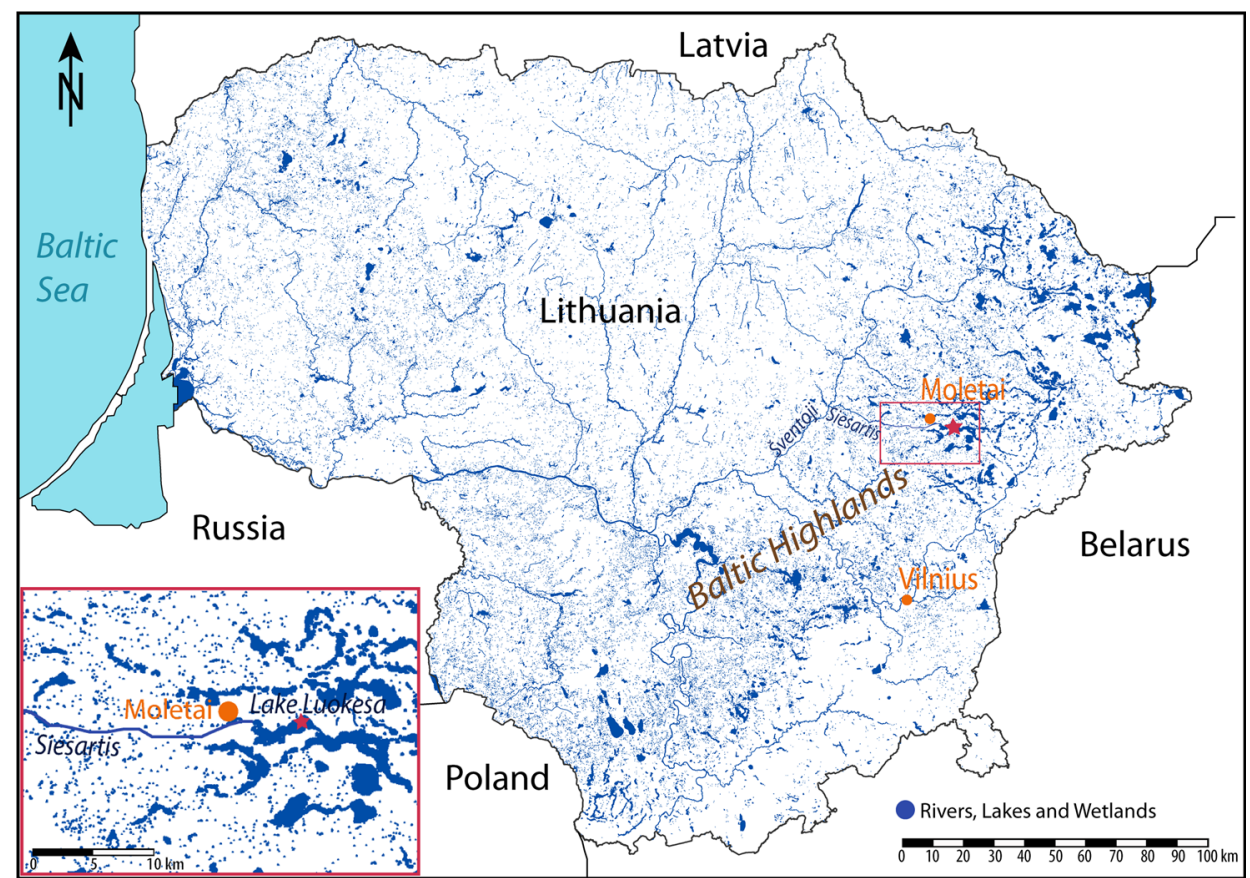

micromorphological studies have become increasingly popular in the analysis of lakeside settlements (Ostendorp 1990, 1996; Krier 1997; Wallace 1999, 2003; Karkanas et al. 2011). Over the last 10 years, the Institute for Integrative Prehistory and Archaeological Science (IPAS), University of Basel, Switzerland, has had the opportunity to micromorphologically examine several wetland settlements on lake shores (Ismail-Meyer and Rentzel 2004; Ismail-Meyer 2010; Huber and Ismail-Meyer 2012).

It was the aim of the present study to reconstruct the site formation processes and environment of this settlement. The key issues included whether the settlement was built over open water, how the organic accumulations formed and if the deposits have been reworked. The results of our investigations will be compared with the already existing analysis of five profile samples taken from Lake Luokesa in the years 2007 and 2008 (Lewis 2007; Motuzaite Matuzevičiūtè 2008).

Geographical and geomorphological setting of Lake Luokesa and archaeological basics

Lake Luokesa is part of an area of lakes located in the eastern part of Lithuania in the Moletai region (Fig. 1). A large area of the country was moulded by the Scandinavian ice sheet during the Nemunas/Weichselian glaciation. Among other glacial forms subglacial tunnel valleys (proglacial valleys) were formed which then filled up with melt water (Guobyte and Satkūnas 2011). The landscape is characterised by hills with plateaux with an altitude of 160-170 $\mathrm{m}$ a.s.1. that are covered with dense forests.
Peatlands are often found in the lowlands, at an altitude of approximately $150 \mathrm{~m}$ above sea level (Motuzaite Matuzevičiūte 2008). In the area of Lake Luokesa fluvioglacial, sandy-gravelly sediments and moraines formed during the latest stages of the last glacial, referred to as Grūda and Baltija (Bitinas et al. 1995; Guobytè and Satkūnas 2011). The relief around the lake is characterised by relatively steep slopes which are covered with solifluction deposits (Bitinas et al. 1995). The soils that have formed on these deposits are sandy-clayey brown soils on the hills and peat soils in the lowlands (Motuzaite Matuzevičiūtè 2008).

Lake Luokesa is connected with several other small lakes through streams; it is fed from the east/south-east and drains towards the west (Fig. 2; Menotti et al. 2005). The morphology of the lake $(2.4 \mathrm{~km}$ long, $0.8 \mathrm{~km}$ wide, maximum depth $47.8 \mathrm{~m}$ ), is dominated by moraine ridges that may have influenced the development of two islands on the lake. Biogenic lake deposits of fine-grained carbonate mud (lake marl) cover large areas of the littoral zone (see Fig. 2). They form a 15-20 cm thick coating on the moraine ridge (Motuzaite Matuzevičiūtè 2008; Menotti et al. 2005). Today there are reed beds located in some places within this area (E. Pranckènaite personal communication). A mapping of the lake floor in combination with aerial photographs (E. Pranckenaite) shows that an elongated shore platform that connects to the eastern island exists at depths down to about $5 \mathrm{~m}$ below the current water level (Fig. 2; Pranckènaite 2014). The fortified settlement of L1 developed on this elongated lake marl peninsula at an unknown time between 625 and 535 cal BC (Fig. 3; Bleicher 2014). 


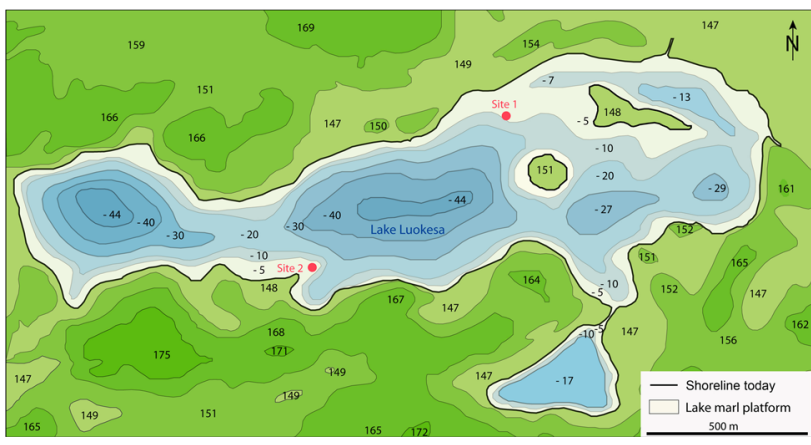

Fig. 2 Topography of Lake Luokesa and its surroundings with the approximate heights in $\mathrm{m}$ a.s.l. The bathymetric heights of the lake are marked as metres below the present-day lake level. The white beach platform emerges when the lake level drops about $5 \mathrm{~m}$ (source of the maps: http://kvr.kpd.lt/heritage/, modified)

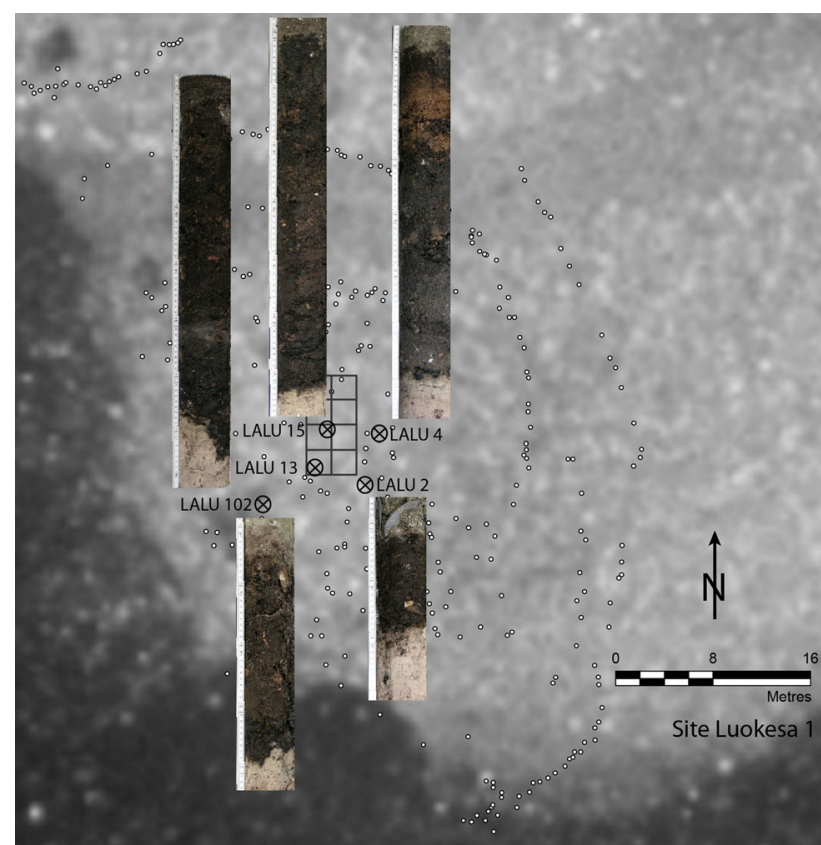

Fig. 3 Lake marl platform (light grey) with the site L1, the piles (dots), the measurement grid for the excavation and the micromorphologically analysed profile columns (crosses) with photographs of the opened columns included (map provided by E. Pranckenaite, modified by B. Pollmann)

The relief of the shore platform near L1 shows that the area with a massive anthropogenic accumulation of organic material is quite small with a size of about $100 \mathrm{~m}^{2}$ (Fig. 4). This area is located approximately in the centre of the zone enclosed by the palisade and can be regarded as the centre of the settlement due to the dense positioning of the poles and high concentration of archaeological artefacts (Pranckenaite 2014). The organic deposit thins out quite rapidly closer to the lake (Fig. 4). This is also the case in the north-east part of the site as the thickness of the organic deposits decreases from $60 \mathrm{~cm}$ (profile LALU 4) to $2 \mathrm{~cm}$ (profile LALU 103) within a distance of $8 \mathrm{~m}$ (Fig. 4; for a section see Fig. 5 in Pranckenaite 2014). The reconstruction of the ground floor planes of the houses by dendrochronological analyses was not possible (Bleicher 2014). The absence of clear floor structures, such as compact loam floors, suggests that the house floors were most likely elevated above the ground (Pranckènaite 2014).

\section{Materials and methods}

During the underwater excavations at Lake Luokesa in the years 2008 and 2009, $12 \mathrm{~m}^{2}$ were excavated and several profiles in tubes of $10 \mathrm{~cm}$ in diameter were collected within the excavation site and the surrounding area for paleoecological study (Figs. 3 and 4, ESM 1; see also Pranckènaitė 2014 and Pollmann 2014a). Five profiles with a well-preserved cultural layer (LALU 2, 4, 13, 15 and LALU 102) were selected for interdisciplinary analysis from L1 (Fig. 3; see also Pollmann 2014a; Heitz-Weniger 2014). These profiles originate from the excavation area, covering a small, central part of the settlement of approximately $12 \times 5 \mathrm{~m}$ (Fig. 3) and a transect (Fig. 4; see also Fig. 3 in Pollmann 2014a and Fig. 3 in Heitz-Weniger 2014). Up to the present it has not been determined whether the profiles were taken from the alleyways or from places within the houses, as the ground floor plans of the houses are not known (Bleicher 2014).

The surfaces of the opened tubes were cleaned and photographed in the laboratory and the recognisable layers were geoarchaeologically described. The pollen sampling was done based on this description (Heitz-Weniger 2014). The entire sequence of occupation layers of every profile was then sampled, including the top and bottom of the adjoining lake deposits, using small plastic containers (ESM 1). It was important to remove as little material from the columns as possible to ensure that sufficient material remained for the study of macroremains (Pollmann 2014a). After gentle drying of the samples, they were cast in epoxy resin under vacuum, and after curing were sawn into slices, referred to as polished sections (ESM 2). At the relevant points, $4.7 \mathrm{~cm}$ long square blocks were processed into 31 covered thin sections of $0.03 \mathrm{~mm}$ thickness (Fig. 5; Beckmann 1997).

The thin sections were correlated with the geoarchaeological layer description of the profiles and described in detail using a polarizing microscope at magnifications from $16 \times$ to $630 \times$ (after Bullock et al. 1985; Stoops 2003; ESM 3 ). Identification of components, such as minerals, clay, bones, ashes and pottery, were made following literature (e.g. Bullock et al. 1985; Fitzpatrick 1993; Schiegl et al. 1996; Stoops et al. 2010). The state of preservation of mollusc shells was evaluated after Cutler (1995). Organic 
Fig. 4 Geomorphological map of the lake marl platform; higher parts in light grey $(99.7 \mathrm{~m}$ a.s.1.), lower parts in dark grey (98.9 $\mathrm{m}$ a.s.1.). The white dots mark the piles found, the grey ones the measurement points. Crosses mark the column samples with the photographs of each column superimposed. Shaded ellipses indicate the approximate cultural layer thickness. The large ellipse indicates the area with a preserved cultural layer less than $15 \mathrm{~cm}$ layer thickness. The medium ellipse shows layer thickness from 15 to $25 \mathrm{~cm}$. The small, central ellipse indicate a layer thickness over $25 \mathrm{~cm}$ (maps provided by E.

Pranckènaite, modified by B.

Pollmann and K. Ismail-Meyer)

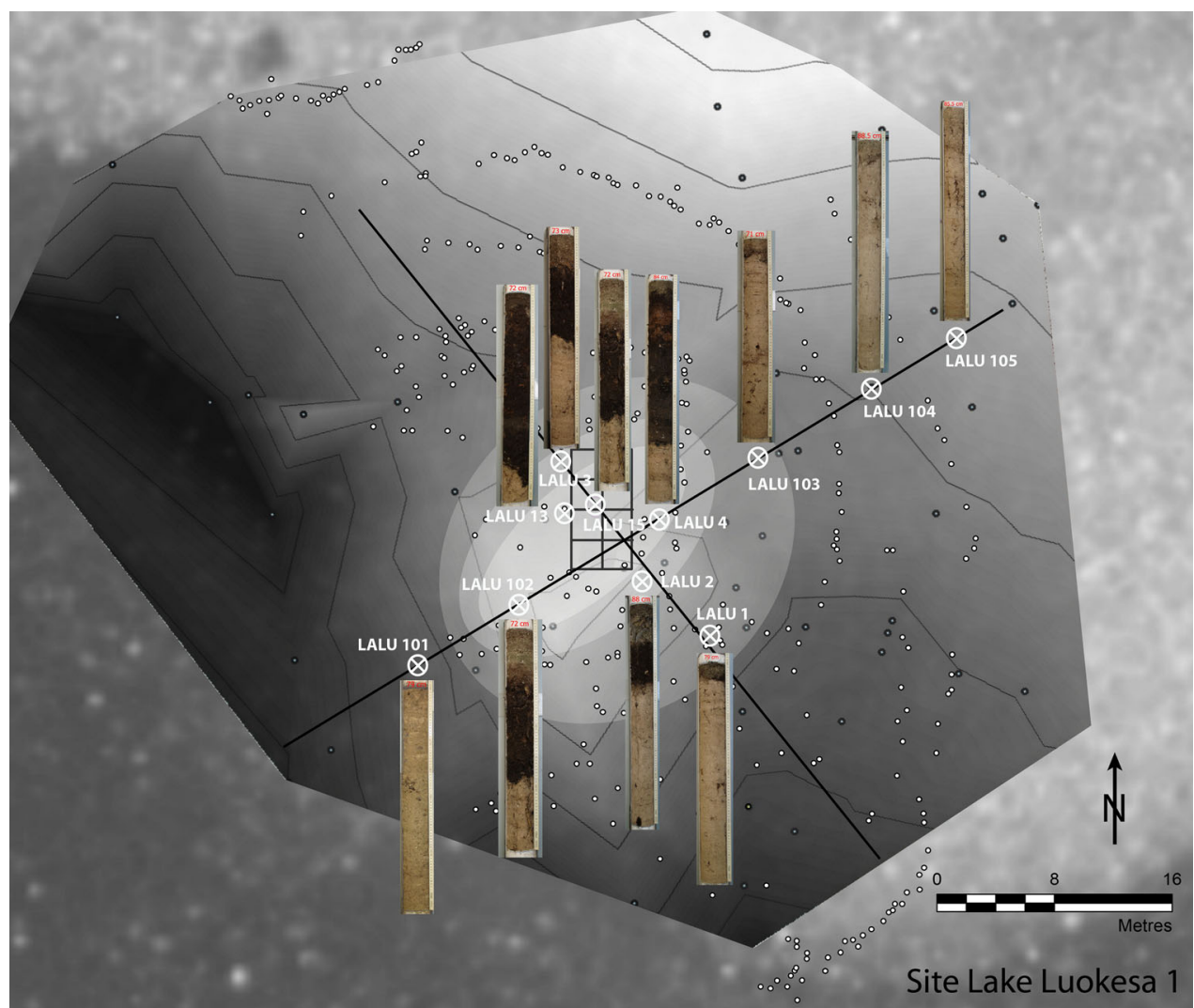

components were estimated after Babel $(1975,1985)$ and Stolt and Lindbo (2010), by the use of reference sections and in close collaboration with the archaeobotanist (Pollmann 2014a). Coprolites (excrement) of domestic animals and micro fauna were distinguished by their composition, shape and structure (after Pawluk 1987; Akeret and Rentzel 2001; Karkanas and Goldberg 2010) and according to our own reference sections. Signs of alteration of organic components were described after Babel (1975), Pawluk (1987), Takeda (1988) and Stolt and Lindbo (2010).

For the environmental reconstruction, sediment types (facies), were defined. In order to compare the density of seeds in each facies, we calculated the approximate number of countable seeds per $10 \mathrm{~mm} \times 47 \mathrm{~mm}$ strip for each layer.

\section{Results}

Lake marl below the cultural layer and post-settlement sediment cover

The base of the profiles contains laminated, light grey calcium carbonate mud containing traces of sand (Table 1; Fig. 5a; ESM 1-3). Only a small amount of organic material is present, consisting of wood, bark, leaves, grass (not specifically identifiable remains of Poaceae and $\mathrm{Cy}$ peraceae) and roots. Remains of aquatic organisms such as molluscs (i.e. Bithynia tentaculata, Valvata cristata, Radix ovata and Amiger crista; Pollmann 2014b), crustaceans (Ostracoda), diatoms, sponge needles and occasionally caddis fly larvae (Trichoptera) are present. Algal residues, usually of stonewort (Charales), can be found in the form of calcified stems and oogonia. These residues are referred to in this paper as limnic elements.

At the top of the lake marl, in the first 10-20 mm below the cultural sequence, the carbonate becomes light brown, dense and sandy (Figs. 5b, 6a, b; Table 1). The colour change is caused by the presence of finely distributed micro-charcoal and very fine plant detritus. Limnic elements such as molluscs and algal remains decrease, while larger pieces of charcoal, bark and grass and the first macro remains of terrestrial origin become increasingly common. The gastropod shells are fragmented; in the western settlement area (in profile column LALU 4) algal boring can be observed (Figs. 4, 6c, d).

The covering layer of cultural deposits also consists of porous lake marl in some parts of the site (Table 1; Fig. 5b). However, in the north-eastern area of the site (columns LALU 2, 13, 15), the top layer consists of up to $50 \%$ sand (Fig. 4). The organic content is very low in the surface layers and almost only consists of roots and reed 
Fig. 5 Scanned thin sections. a Thin section LALU 4.2.3, at the bottom the beige lake marl which is denser in the upper part due to trampling. The limnic sediment is overlain by the basal part of the cultural sequence, consisting here of black charcoal and bark imbedded in sand. b Thin section LALU 102.1.2, a sand layer at the bottom (light grey) is covered by an organic accumulation (dark coloured), possibly a dung layer, which has been eroded and covered by lake marl (grey sediment in the upper half) after the final flooding. $\mathbf{c}$ Thin section LALU 102.2.4, organic layers of the cultural sequence consisting mainly of big charcoals, wood, bark remains and detritus. $\mathbf{d}$ thin section LALU 4.2.1, a dense anthropogenic sand layer with gravels. In the topmost part there is an inwash of fine sand from the hinterland with detritus (arrow), covered by coarser sand grains containing charcoal
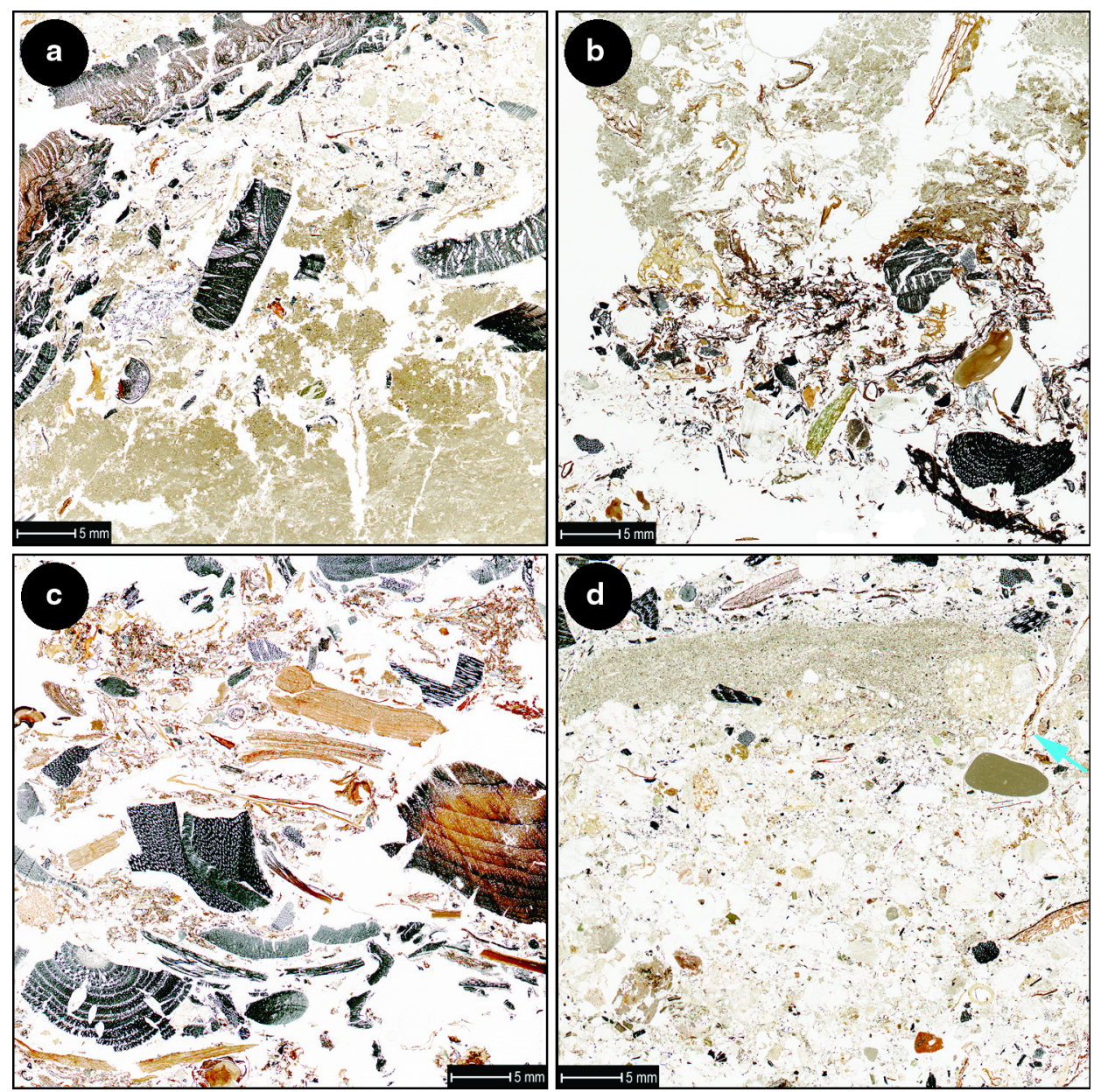

Table 1 Descriptions of the different facies found at the site L1; -, not existent; x, rare/weak; xx, frequent/clear; xxx, very frequent/strong

\begin{tabular}{|c|c|c|c|c|c|c|c|c|c|c|c|c|c|c|c|c|c|}
\hline Facies & 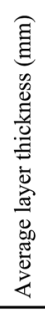 & $\begin{array}{l}\text { 胥 } \\
\text { 总 } \\
\end{array}$ & 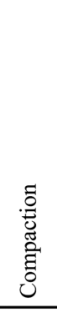 & 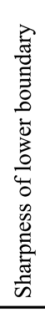 & $\begin{array}{l}\text { वे } \\
\text { 离 } \\
0 \\
0 \\
0 \\
0\end{array}$ & 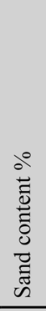 & 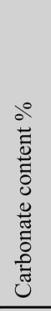 & 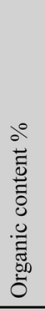 & 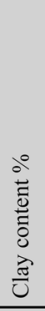 & 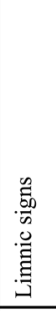 & 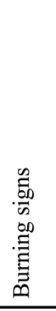 & 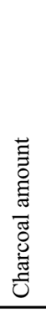 & 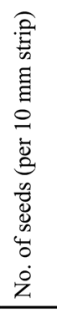 & 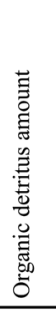 & 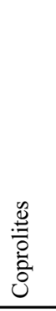 & 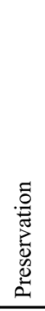 & 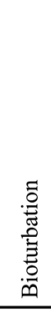 \\
\hline Burning layers & 11 & $\mathrm{x}$ & - & $\mathrm{x}$ & 15 & 42 & 6 & 32 & 5 & - & $\mathrm{xxx}$ & $\mathrm{xx}$ & 1.5 & $\mathrm{x}$ & $\mathrm{x}$ & $\mathrm{x}$ & $\mathrm{x}$ \\
\hline Clay layers & 25 & $\mathrm{x}$ & $\mathrm{x}$ & $\mathrm{x}$ & 14 & 54 & 0,5 & 16 & 16 & - & $\mathrm{x}$ & $\mathrm{x}$ & 0.4 & $\mathrm{x}$ & - & $\mathrm{xx}$ & $\mathrm{x}$ \\
\hline Sandy layers with detritus & 13 & $\mathrm{xx}$ & $\mathrm{x}$ & $\mathrm{xx}$ & 15 & 50 & 2 & 28 & 5 & - & $\mathrm{x}$ & $\mathrm{x}$ & 1.6 & $\mathrm{x}$ & - & $\mathrm{x}$ & $\mathrm{x}$ \\
\hline Sandy layers with gravels & 6 & $\mathrm{xx}$ & - & $\mathrm{xx}$ & 20 & 43 & 2 & 32 & 3 & - & $\mathrm{xx}$ & $\mathrm{xx}$ & 0.6 & $\mathrm{xxx}$ & $\mathrm{x}$ & $\mathrm{x}$ & $\mathrm{x}$ \\
\hline Dung layer & 27 & $\mathrm{x}$ & $\mathrm{x}$ & $\mathrm{xx}$ & 23 & 8 & 1 & 67 & 1 & - & - & $\mathrm{x}$ & 1.7 & $\mathrm{xx}$ & $\mathrm{xxx}$ & $\mathrm{x}$ & $\mathrm{x}$ \\
\hline Organic layers with signs of alteration & 17 & $\mathrm{xx}$ & $\mathrm{x}$ & $\mathrm{x}$ & 24 & 18 & 1 & 54 & 3 & - & $\mathrm{x}$ & $\mathrm{x}$ & 2 & $\mathrm{xx}$ & $\mathrm{x}$ & $\mathrm{x}$ & $\mathrm{x}$ \\
\hline Organic layers with good preservation & 22 & $\mathrm{x}$ & - & $\mathrm{x}$ & 28 & 14 & 1 & 57 & 0.5 & - & - & $\mathrm{xx}$ & 1.4 & $\mathrm{xx}$ & $\mathrm{x}$ & $\mathrm{xx}$ & $\mathrm{x}$ \\
\hline Covering lake marl layer & - & $\mathrm{xx}$ & - & $\mathrm{xx}$ & 23 & 9 & 62 & 6 & - & $\mathrm{xxx}$ & - & - & - & $\mathrm{x}$ & - & $\mathrm{x}$ & $\mathrm{x}$ \\
\hline Horizon of installation & 8 & $\mathrm{x}$ & $\mathrm{xx}$ & $\mathrm{x}$ & 12 & 11 & 61 & 16 & - & $\mathrm{xx}$ & - & $\mathrm{x}$ & 1.8 & $\mathrm{x}$ & - & $\mathrm{xx}$ & $\mathrm{x}$ \\
\hline Lake marl & - & $\mathrm{xx}$ & - & $\mathrm{x}$ & 12 & 2 & 80 & 6 & - & $\mathrm{xxx}$ & - & - & - & - & - & $\mathrm{xx}$ & $\mathrm{x}$ \\
\hline
\end{tabular}



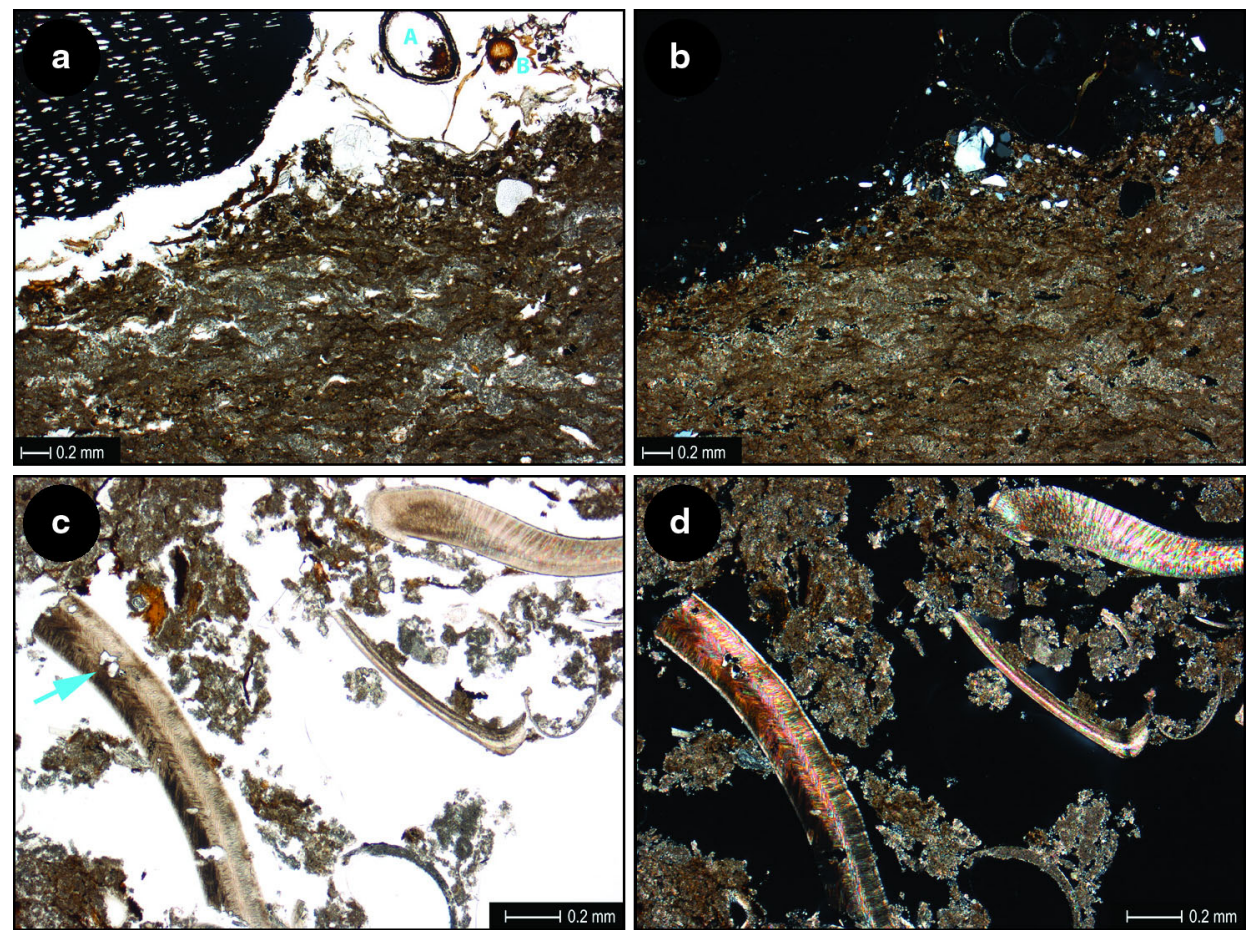

Fig. 6 Photomicrographs of limnic sediments. The pictures in plain polarized light show the carbonate lake marl and mollusc shells in beige to grey, organic remains in brown and black, quartz grains appear transparent. With crossed polarisation the lake marl shows a beige to grey colour, the mollusc shells appear grey, pinkish and greenish and quartz grains white-bluish grey; a) LALU 13.2.4, plain light, compact lake marl of the installation horizon containing organic detritus. At the surface there are anthropogenic remains trampled into

rhizomes. It is striking that it is in these outer layers that the largest numbers of gastropods, often showing signs of algal boring, are found (Fig. 6c, d).

Organic facies of the cultural layer

Above the lake marl, dark brown organic layers are common (Table 1; ESM 1,2). These deposits all consist on average of over $50 \%$ plant residues, while the sand content is at highest $20 \%$ (Fig. 5c; Table 1). Rare limnic components can be observed at the transition to the lake marl. The average carbonate content of $3 \%$ is mainly due to the presence of carbonate wood ash. Further, there are charcoal, burnt aggregates (sometimes containing phosphates) and quartz with melting rims, which can be observed regularly. Gravel and ceramics (Fig. 7a) can also be determined. The micromorphologically identifiable plant remains can mainly be attributed to wood and bark fragments, grass remains (Poaceae and Cyperaceae; Fig. 7b, c), mosses (Bryophyta and Sphagnum; Fig. 7d), branches and leaves from foliage

the lake marl as quartz grains (see b), a charcoal (top left), a macro remain (A) and moss (B). b same as a, crossed polarisation, note the quartz grains. c LALU 102.1.1, plain light, several mollusc shells embedded in the lake marl. The shells show different stages of preservation such as algal boring (arrow) and dark grey, weathered parts (aragonite transformed into calcite). At the top right hand side, a well preserved bivalve shell. $\mathbf{d}$ same as $\mathbf{c}$, crossed polarisation

(Fig. 7e). There are also numerous glumes and grains of Panicum miliaceum (millet, Fig. 7f) and other cereals (Fig. 7g-i), Fragaria vesca (strawberry, Fig. 7j) different Rubus species, Camelina sativa (false flax), seeds of Chenopodiaceae (goosefoot family) and rarer Corylus avellana shells (hazelnut, Fig. 8a) as well as a charred Pisum sativum (pea, Fig. 8b). In addition, there are different coprolites (Fig. 8c-e). These show different states of preservation and are sometimes fragmented (Pollmann 2014b); dung spherulites are not preserved. Fish bones are rare and some of them are charred (Fig. 8f). Some insect remains could also be recognised (Fig. 8g). Fine organic detritus is quite common. Fungal spores (sclerotia) and droppings of micro fauna, such as Oribatida (mites), Collembola (springtails) and/or Enchitraeida (pot worms), are rather rare (Fig. 8h; Pollmann 2014b). On occasion dopplerite (dissolved organic matter; Fig. 8i) and organic crusts, i.e. elongated organic aggregates showing poor cell preservation, can be observed. The regular traces of roots and rhizomes can be attributed mainly to reeds (Fig. 8j). 
Fig. 7 Selected details from the Lake Luokesa thin sections, all in plain light; a LALU 4.2.2, a cross section through a pottery fragment with coarse tempering (granite fragments). b LALU 2.2 , a grass stem, probably a cereal, seen in cross section, with the characteristic vascular tissues (arrow). c LALU 4.1.1, a Cyperaceae leaf in cross section (identification by Ö. Akeret, IPAS). d LALU 13.2.3, peat bog (Sphagnum) with a dark coloured stem and the almost transparent cells of the leaves. In the upper left corner a quartz grain (greyish-transparent). e LALU 13.2.1, at the bottom a piece of bark overlain by a dark foliage leaf in the middle with visible palisade tissue (arrow) and a charcoal in the top left corner. f LALU 102.2.4, a burned seed of Panicum miliaceum with the black, burst starch in the middle, encircled by the seed coat. g LALU 4.1.3, a charred cereal grain with the burned, bubbly starch, the seed coat with the marked crease (right arrow) and the glume still covering the grain (left arrow). h LALU 4.1.3, burned glumes. i LALU 4.1.3, cereal porridge with a recognizable cereal seed coat (arrow, identification by B. Pollmann). j LALU 4.1.1,

Fragaria vesca seed

(A) overlain with black grass remains, probably from cereals (B)
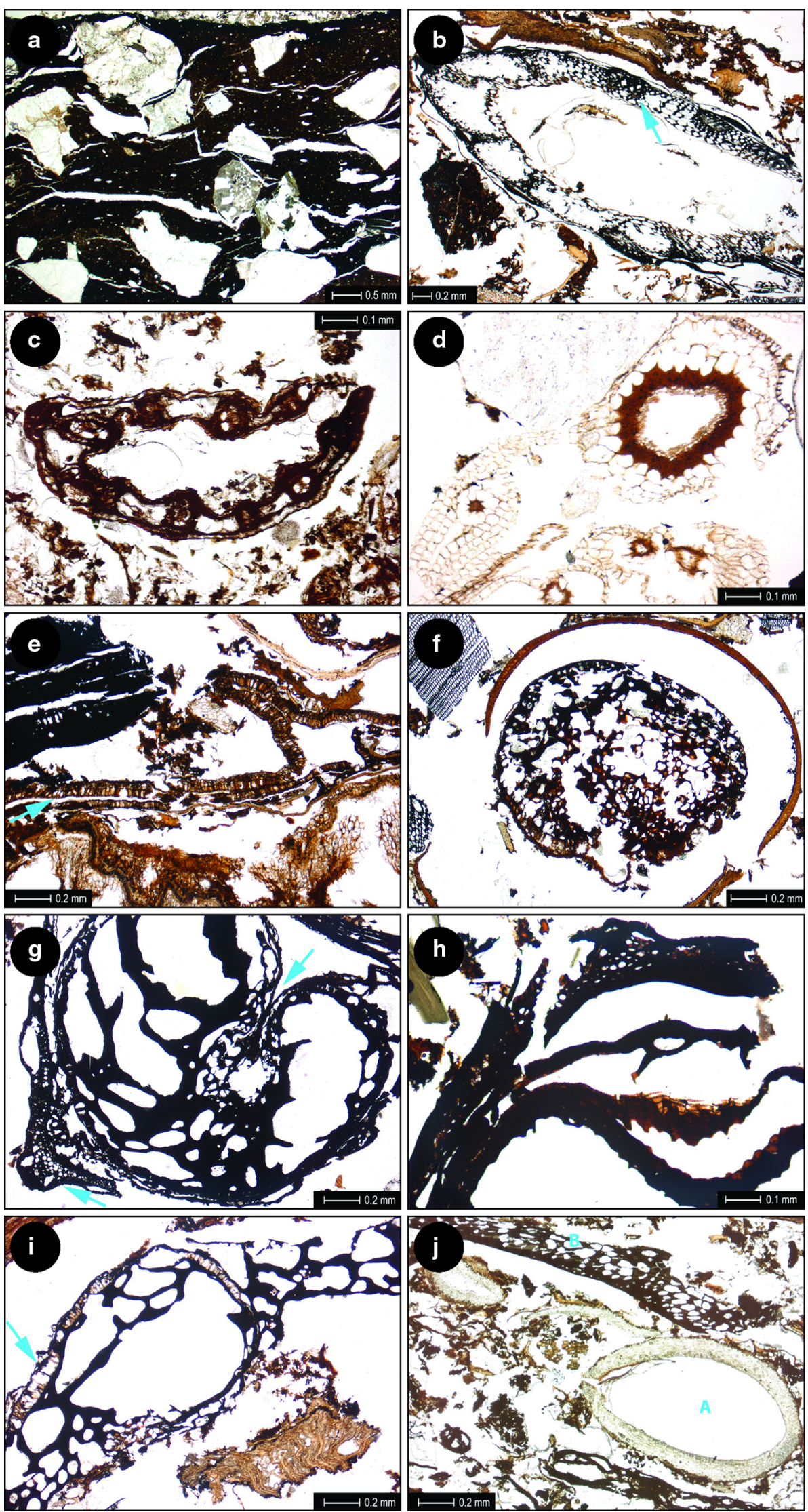
Fig. 8 Selected details from the Lake Luokesa thin sections, all taken in plain light; a LALU 102.2.1, Corylus avellana shell (top right corner) with two resin ducts, below a burned cereal grain without glumes (arrow). b LALU 4.2.3, a partially charred Pisum sativum with the bubbly starch in the middle, surrounded by the preserved seed coat. c LALU 13.1.2, a well preserved, whole sheep/ goat coprolite with the typical, convolute internal structure and the denser rim. d LALU

102.2.1, a coprolite of a small rodent, probably a field mouse, identifiable because of the size and the dense structure. e LALU 102.2.4, possible pig coprolite with very high fragmentation rate of the remains

(identification by R. Macphail). f LALU 13.2.4; two burned fish or amphibian bones (light brown) beside a dark piece of bark. g LALU 4.2.4, insect remains with the chitin showing tiny hairs on the left side, embedded in sandy sediment. h LALU 15.1.2, coniferous wood in transverse section showing an annual ring with dense late wood (arrow). In the middle part, in the early spring wood, there are some mite droppings, indicating a slight decomposition of this wood fragment. i LALU 102.1.2, dopplerite, the result from decayed organic remains. At the top right hand corner a burned cereal grain $(\mathbf{A})$ and in the middle a fragmented Fragaria vesca seed (B). j LALU 2.1, rhizome of a reed, grown through the cultural layers after the settlement phase (identification by B. Pollmann)
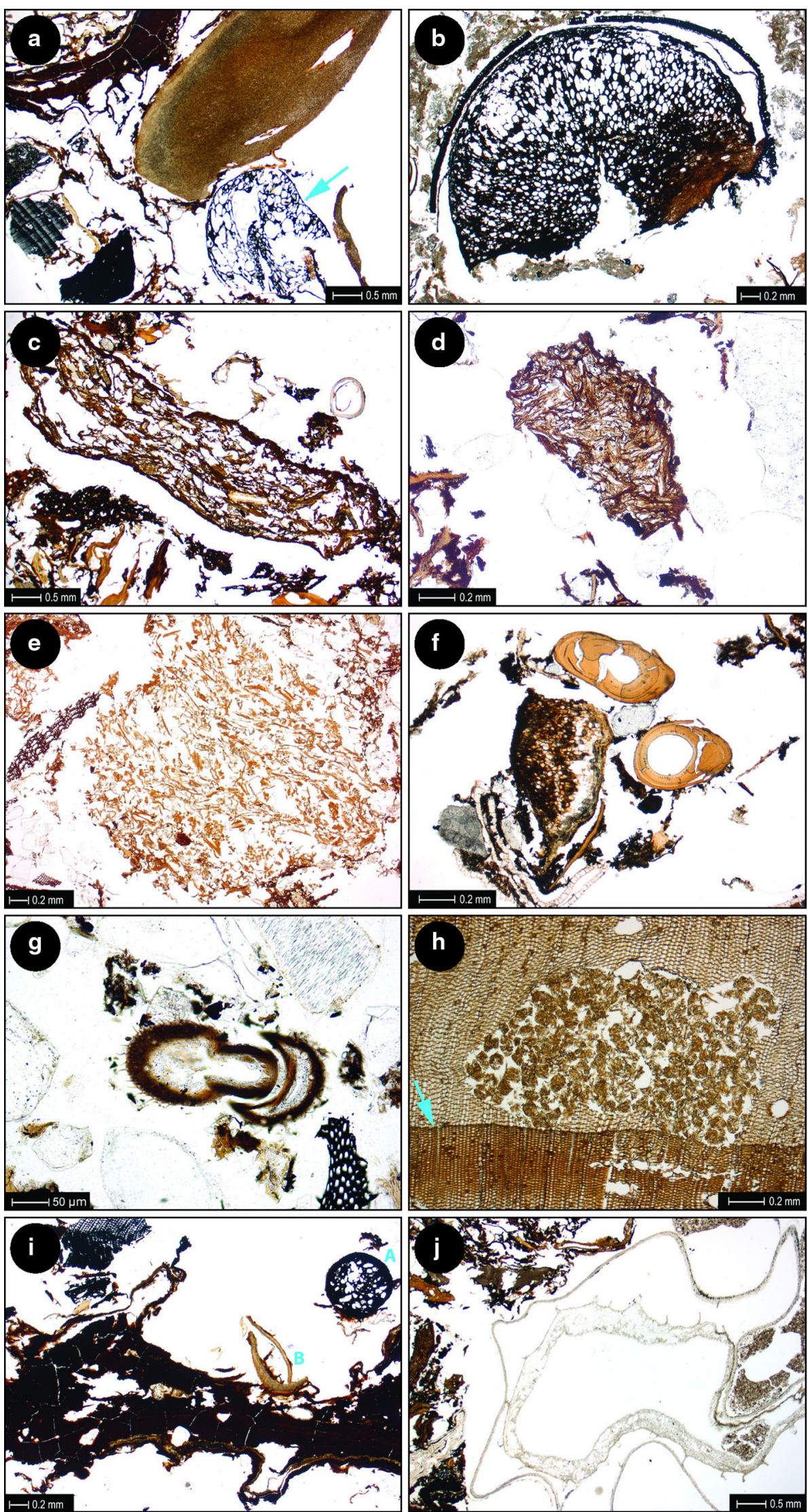

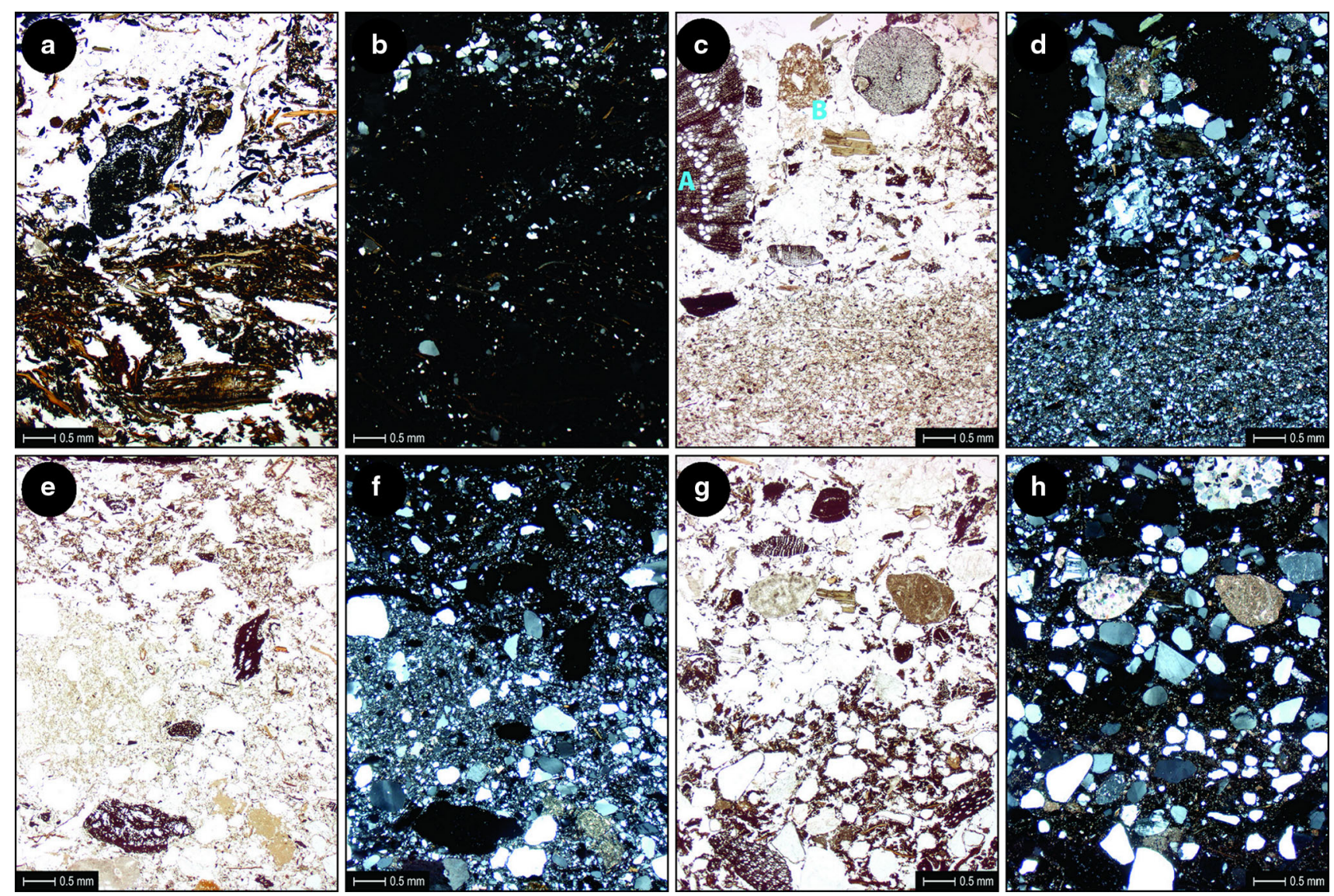

Fig. 9 Photomicrographs from the main facies from L1; the pictures in plain light show organic remains in brown colour, quartz grains transparent to greyish and loam in beige. In crossed polarized light organic remains appear black, quartz in white-bluish-grey and loam shows a fine mottling in grey-black colours with embedded quartz grains. a LALU 13.2.1, plain light, organic layer with detritus (lower part) showing signs of desiccation and crust formation. The organic accumulation is overlain by a sandy inwash in the uppermost part (see b). b same as a, crossed polarizers, the sand content of this layers is very low. c LALU 4.2.1, plain light, inwash of fine sand with detritus (lower part), overlain by coarser sand containing wood remains

(A) and a loam aggregate (B); detail from Fig. 5d). d same as c, crossed polarizers, the thorough sorting of the fine sand in the lower part is clearly visible, the upper sand layer is less sorted. e LALU 13.2.2, plain light, a compact clay containing sand, a possible loam floor, overlain by a brown, organic layer rich in detritus, perhaps remains of a weathered functional layer. $\mathbf{f}$ same as $\mathbf{e}$, crossed polarizers; the dense structure of the clayey sand is clearly visible. g) LALU 13.2.3, plain light, a burning layer (lower part) with rounded middle sand, scattered micro charcoal (and ashes in the lower half). h same as $\mathbf{g}$, crossed polarizers, the scattered ashes in the lower half of the picture are visible as grey dots between the quartz grains

The organic deposits can be divided into three sub-facies (Table 1):

- Organic layers with good preservation (Fig. 5c) The loose organic deposits consist mainly of brownish, horizontally aligned residues showing a spongy structure. They contain around $15 \%$ rather poorly sorted fine to coarse sand. The density of seeds (1.4 seeds per $10 \mathrm{~mm} \times 47 \mathrm{~mm}$ strip) is relatively low compared to other facies. Distributed regularly in the matrix are detritus and micro charcoal.

- Organic layers with signs of alteration (Fig. 9a, b) These compact layers show often a spongy or a fine granular structure. They consist of dark brown organic residues often in the form of detritus. Microfaunal droppings, dopplerite, sclerotia and organic crusts are

also present. The seed density $(2$ seeds per $10 \mathrm{~mm} \times 47 \mathrm{~mm}$ strip) is the highest for the site.

- Organic layers with dung remains (Fig. 5b) The layers show a spongy structure and contain coprolites and concentrations of highly fragmented plant remains of reddish-brown colour. With $8 \%$ sand content these layers have the lowest sand content of anthropogenic deposits while simultaneously having the highest organic amount of over $65 \%$ (average porosity 19-27\%). The seed density is elevated with 1.7 per $10 \mathrm{~mm} \times 47 \mathrm{~mm}$ strip. The content of micro faunal droppings, dopplerite, sclerotia and organic crusts is quite high. The organic spectrum does not differ significantly from the two organic facies described above. 

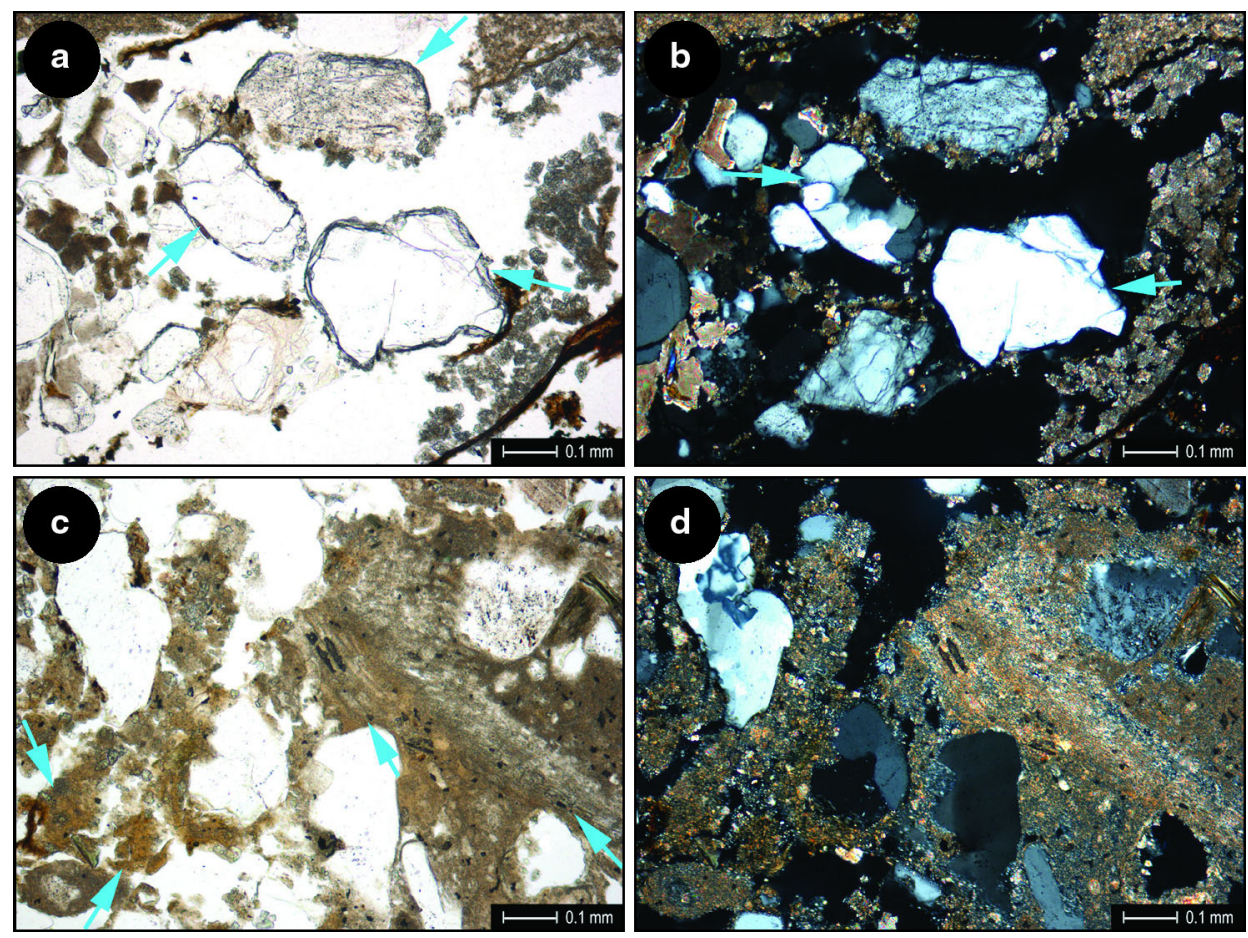

Fig. 10 Thin section pictures from burning features. The pictures in plain light show carbonate ashes in beige-grey colours and quartz grains appear nearly colourless. In crossed polarized light carbonate ash shows beige-brown colours and quartz grains appear whitebluish-grey. a LALU 4.1.4, plain light, detail from a burning layer with quartz grains showing melting rims (arrows) and carbonate ashes. b same as a, crossed polarizers, the quartz grains show an

Sandy intercalations within the cultural layer sequences

Almost all the profiles-with the exception of LALU 2 located in the south-east-show several sandy intercalations that represent two facies (Fig. 3; Table 1).

- Sandy layers with gravel: here the components are well aligned and consist of over $40 \%$ fine sand to fine gravel, which is moderately sorted (Figs. 5d, 9c, d). The lower layer boundaries are often pronounced; the surfaces are compact in some cases. The organic content is quite high, at $30 \%$, which comes from wood, bark, peat moss and rarely grass and leaves. In some layers, very high charcoal amounts and organic crusts can be observed. The seed content is elevated, with 1.6 seeds per $10 \mathrm{~mm} \times 47 \mathrm{~mm}$ strip. Ashes and charred aggregates are frequently present. A part of the sand consists of well-rounded medium sand, often showing melting rims and undulatory extinction under polarized light (Fig. 10a, b).

- Sandy layers with detritus: There are some striking levels of fine sand, which have a high density and contain a clay matrix with high amounts of organic detritus (Figs. 5d, 9c, d). They are well sorted and show

undulatory extinction (arrows), probably due to heating. The beige coloured ashes are clearly visible. c LALU 4.2.2, plain light, compact carbonate ashes showing plant pseudomorphs (arrows on right), and brown parts probably containing iron and phosphate (arrows on left, perhaps a burnt coprolite). d same as c, crossed polarizers, the ashes appear beige-dark grey

a gradation. Here, the lower layer boundaries are clearly visible also. In addition to a fine sand content of nearly $50 \%$, the amount of organic remains-compared with the gravelly sand layers-drops somewhat and mainly originates from bark and Sphagnum. Micro charcoal, ash and burnt aggregates are rare.

Clayey layers within the cultural layer

Clay-rich layers in the site L1 are very rare (Table 1). Clay amounts of up to $10 \%$ are found in organic layers with signs of alteration and sandy deposits. They are represented by aggregates of more than $6 \mathrm{~mm}$ size, which consist of residual clay (E horizon). Aggregates from clay accumulation horizons (Bt horizon) are less common. Both types occur due to soil formation above a moraine, where in the A horizon clay minerals are washed out (E horizon), translocated to the bottom and accumulated in the underlying Bt horizon. Three clay rich layers with a maximum clay content of $20 \%$ can be determined in the LALU 4 profile column. Additionally, in several layers, a fine sandy-clayey matrix is present (total mineral content between 60 and $70 \%$ ) which is mixed with about $15 \%$ 
organic material (bark and grass remains). In the profile column LALU 13 (Fig. 3), such a layer forms a $3 \mathrm{~cm}$ thick, compact level which is overlain by a weathered organic layer (Fig. 9e, f).

\section{Discussion}

History of the site reflected in sediment micromorphology

\section{Lake marl formation}

The carbonate mud below the cultural layers can be associated with lake marl; formation of it is well known in many lakes in mid-latitudes as well as in the Baltic states (Magny 2004; Novik et al. 2010; Punning et al. 2005). Lake marl started to form during the early Holocene and originates from the biogenic precipitation of carbonates, mainly due to the metabolism of aquatic plants, both macrophytes (Najas and Potamogeton) and algae like Characeae. The metabolic carbonate products are deposited on the bottom where they form micritic deposits. Within these deposits, remains of flora and fauna such as mollusc shells and calcified algae are present. In undisturbed areas below the wave base, laminations may be observed, consisting of denser micrite layers with loose intercalations of mostly algal remains, probably due to changing types of precipitation (Freytet and Verrecchia 2002). The appearance and composition of lake marl allow a rough estimation of the water level during its precipitation, meaning that fluctuations in the water level, and therefore shifts in the shoreline, become visible. Thus lake marl showing lamination has formed below the wave base in a calm environment (Digerfeldt et al. 2007; Huber and Ismail-Meyer 2012; Ismail-Meyer et al. 2013). Closer towards the shore in the littoral zone or after a lake regression, fine sands were in-washed by fluvial processes. Wave action led to reworking and leaching of the lake marl, so that a lag deposit may have arisen in the form of unstratified, sandy and mollusc rich lake marls (Brochier 1983; Ostendorp 1990; Platt and Wright 1991; Magny 1992; Freytet and Verrecchia 2002; Digerfeldt et al. 2007). If lake marl is exposed to air, a hard, walkable-on crust forms on the surface (Monnier et al. 1991; Jacomet et al. 2004) and exposed mollusc shells are quickly altered by weathering and algal boring (Cutler 1995; Ostendorp 1996).

The laminated lake marl from Lake Luokesa has been precipitated below the wave base and show that before the settlement development the environment was very calm, which is also supported by the presence of gastropods indicating clear, plant-rich water (Werner and Reitner 1989). In the top $1-2 \mathrm{~cm}$ the start of a regression can be seen in the form of reworked lake marl (destruction of laminations in the littoral zone). Traces of iron oxide, such as those observed by Motuzaite Matuzevičiūte (2008) were not apparent in the profiles studied by us. The abrupt transition between lake marl and the cultural layer indicates that the platform emerged as a result of a lower lake level causing its surface to dry out. This led to the exposure of an oblong lake marl platform from the coast to the eastern island (Fig. 2). In the dry zone of the riparian area, the settlement of Lake Luokesa was founded during the LBAEIA.

\section{Cultural layers}

The area was settled only after a hard, accessible surface was formed due to desiccation, and not over open water (suggested by Lewis 2007; Menotti et al. 2005). This is indicated by the sharp transition between the dense lake marl and the organic layers. The good preservation state of the mollusc shells and pollen, such as the lack of ferric precipitations, indicates only a short hiatus in terms of several weeks before the platform was settled (see also Motuzaite Matuzeviciute 2008; Heitz-Weniger 2014). There is evidence of a slight superficial compaction of the lake marl surface, which was due to anthropogenic (and animal) trampling during the building activities. The first anthropogenic remains, such as charcoal, seeds, wood and bark chips were trampled into the lake marl and formed a 5-10 mm thick so-called "installation horizon", which can be observed in many lakeside settlements (Ismail-Meyer and Rentzel 2004; Huber and Ismail-Meyer 2012; IsmailMeyer et al. 2013). The organic layers derive from anthropogenic (and animal) activities and cannot be attributed to natural peat growth (as suggested by Lewis 2007 and Motuzaite Matuzeviciute 2008); the exceptions were some onsite growing annual herbs (Pollmann 2014b). Organic layers formed by the inhabitants and animal activities in, beneath and around the houses; coprolites of sheep/goats, small rodents (field mouse?), possibly cattle, pigs and dogs could be recognized due to their composition, shape and internal structure (Fig. 8c-e; Akeret and Rentzel 2001; Karkanas and Goldberg 2010). Dung spherulites, formed mainly in the intestines of herbivores and representing often the only remaining sign of coprolites in terrestrial environments, generally do not occur in lakeside settlements as they have been most probably dissolved (M. Canti personal communication). Activities within the settlement which can be recognized through micromorphological investigations are house building and preparation of timber (wood and bark chips, loam aggregates), crafts (granite boulders as temper for ceramic production, see also Pollmann 2014a), food preparation and consumption (fruits and seeds, threshing, cereal porridge, 
nut shells, fish and amphibian bones), stabilization and isolation of the ground (bark, mosses, twigs), and animal husbandry (coprolites, branches, leaves and grass as litter and feed; Fig. 7b, c, e; Pollmann 2014a). The weakly calcareous acid-base balance (pH between 7.4 and 7.8; Pollmann 2014b) ought to have supported fish bone preservation on the site (Lyman 1994) since it can be assumed that fishing was practised at the time (fishnet finds are present, Pranckenaite 2014). The fact that they are so rare (20 fish and amphibian bones, of which 6 had burn marks; Fig. 8f) may be explained by an extensive absence of fish related waste, as cleaning, consumption and disposal of fish could have occurred well outside the sampled area. The use of fire is shown by charcoal, calcitic wood ash, burnt aggregates (possibly burnt dung, R. Macphail personal communication) and quartz grains with melting rims (Fig. 10). The latter most probably originate from the socalled Jotnian Sandstones, transported from Sweden by glacial activity (V. Motuza personal communication). They were found in and around fireplaces (E. Pranckènaite personal communication). As melting rims on quartz are formed at temperatures from $800{ }^{\circ} \mathrm{C}$ upward (Courty et al. 1989), we assume that the inhabitants gathered sandstones in the nearby moraines for use as hot stones; the continuous heating and cooling leading probably to the melting features and dismantling of grains (Fig. 10). Cleaning of fireplaces may have led to the formation of sandy layers with strong indications of burning. Sand, as a regular component of anthropogenic layers, may also be interpreted as weathered loam aggregates from house walls and floors (U. Leuzinger personal communication).

Compaction due to trampling can be seen more prevalently on minerogenous deposits (Magny 1978); waterlogged organic layers seem not to conserve visible traces of compaction as they swell up again quickly as peats (IsmailMeyer and Rentzel 2004). In the settlement L1 trampling is most clearly distinguishable on the installation horizon (Figs. 5a, 6a, b). Additionally there are several compacted sand levels, which are shown most clearly by the profiles from LALU 4 and 13 (Figs. 3, 5d, 9c, d).

\section{Environmental influences}

During the settlement phase organic layers showing good preservation accumulated, indicating waterlogged, anoxic conditions. It is known that organic accumulations can act as a 'sponge' and raise the local water table, so that a fringe of capillary water is drawn up (Kenward and Hall 2000; Gastaldo and Demko 2011; Ismail-Meyer and Rentzel in press). Further, these accumulations show strong water retention and remain wet for a long time span (Corfield 2008; Charman 2009). A combination of high sedimentation rates and very fast sealing of remains led to an extraordinary preservation. Also phases of falling groundwater levels can be detected by the way that organic layers with signs of decay have arisen and organic detritus formed (organic particles measuring between $0.45 \mu \mathrm{m}$ and $1 \mathrm{~mm}$; Mitsch and Gosselink 2007; Gastaldo and Demko 2011). As waterlogged organic layers, such as natural peats, have about $80 \%$ of their pore space filled with water, desiccation leads to a rapid subsidence and collapse of this pore space (Mitsch and Gosselink 2007; Lindsay 2010). The compact, spongy structure in decayed organic layers may be the result of such a process. In some parts, microfaunal activities (mites, springtales and/or pot worms) led to microaggregated structures. At least some slightly acidic phenomena occurred, as the formation of dopplerite and organic crusts indicates (Stolt and Lindbo 2010). When anthropogenic, non-graded sand is the major component of a layer, this may be the result of plant matter decay, where sand was secondarily enriched due to soil formation. Many sandy layers from L1 show strong signs of alteration, so that a halt in sedimentation and a small hiatus must be postulated in such cases. Roots and rhizomes of reeds are most probably of recent origin and led to disturbance of deposits, especially in the upper half of the cultural sequence.

Layers can be affected by flooding caused by lake transgression or runoff from the hinterland (French 2003; Goldberg and Macphail 2006; Digerfeldt et al. 2007). From the micromorphological view it is obvious that due to the continuous fine stratification of the deposits, no general reworking of the layers due to lake flooding has occurred; the consequence would have been a general homogenization (Huber and Ismail-Meyer 2012; Ismail-Meyer et al. 2013). Only the basal $1-2 \mathrm{~cm}$ of the anthropogenic layers contain sparse limnic signs, which are most probably due incursions of human and animal trampling. The rest of the anthropogenic sequence up to the top shows no limnic influences.

Runoff from the hinterland onto low ground, with inwashing of sand and silts into lakes and peatlands, is well known, even on gently sloping areas (Turnbaugh 1978; Baker et al. 2009; Zolitschka et al. 2003). Furthermore, forest clearing and human land use enhances destabilisation of slopes, soil erosion and sediment transfer to low ground (French 2003; Digerfeldt et al. 2007; Menotti 2012). Organic accumulations seem to show special behaviour with respect to runoff; $98 \%$ occurs in the topmost $3 \mathrm{~cm}$, while the deeper, water-saturated layers are not affected (Holden and Burt 2003; van der Valk 2006; Charman 2009; Baker et al. 2009). This may be one explanation of why the anthropogenic successions in lakeside settlements are not eroded completely. In the settlement L1, the difference in height between the lake marl platform and the ridge located to the north is about 
$25 \mathrm{~m}$ at a maximum distance of about $500 \mathrm{~m}$ (Fig. 2). During snowmelt it is conceivable that fine sand and silt was eroded from the slopes and washed into the settlement, which resulted in well sorted and graded sandy layers (containing no limnic signs), as seen in the profile LALU 4 and 13 (Figs. 5d, 9c, d). This event must have had a certain impact as the distinct lower limits of such sand layers show erosion of the exposed sediments; loose material on the surface was worked up and re-deposited together with sand, while the water-saturated layers below were not affected (Ismail-Meyer and Rentzel in press). Since such sand inundation is only present during the occupation phase, it can be assumed that it was probably related to slash and burn land clearing which is known to have been prevalent in the Baltic region after the end of the Bronze Age (Kabailienè 2006; Stančikaitè et al. 2002, 2004; Gaigalas and Dvareckas 2002).

Abandonment of lakeside settlements often occurred due to a fire incident, poor condition of the houses, disuse or persistent flooding from the lake which made further occupancy impossible (Menotti 2012). Micromorphologically, it is difficult to detect the reason for abandonment, as the subsequent flooding also led to erosion of the topmost sediments. The remains of a settlement fire are washed away quickly due to the low specific weight of charcoal (Macphail et al. 2010). Further, water level fluctuationsoften due to modern lake level corrections-can cause lakeside settlements to be exposed to terrestrial conditions causing them to be rapidly weathered. The abandonment of L1 was most likely not due to a settlement fire or flooding, but to simple desertion, which is indicated by the poorer preservation of remains observed in the upper part of all the profiles (Pollmann 2014a). After a short period-before a humic horizon could develop-the lake level rose and led to erosion of the topmost layer and the formation of a reworked lag deposit (Fig. 5b).

\section{Does the cultural layer composition reflect climate seasonality?}

In the case of lakeside settlements it can be assumed that several natural processes, which may have been connected to seasonal variations, affected the cultural sequences, such as phases of higher and lower groundwater table or inundation from the lake and from the hinterland. Sedimentation rates and loss of volume due to desiccation are also connected to seasons, which seem to have a further influence on the average layer thickness of the different facies as compared between the profile columns (which have been calculated for this project for the first time; Table 1). Possible dung layers show the highest layer thickness with an average of $27 \mathrm{~mm}$, organic layers with good preservation $22 \mathrm{~mm}$ thickness, while the organic layers with signs of alteration are $17 \mathrm{~mm}$ and sandy layers $10 \mathrm{~mm}$ in thickness. This shows that cattle stands probably had the highest sedimentation rates (litter, foddering and dung), even when they have been affected by desiccation. Organic layers with signs of alteration lost some volume due to desiccation. Sandy layers seem to have lower sedimentation rates (graded fine sands) or have lost almost all the organic matter and have therefore the smallest average thickness. If one compares the average layer thickness through the profile columns, the profile LALU 13 shows the highest values with $22 \mathrm{~mm}$, followed by LALU 15 with $19 \mathrm{~mm}$ and LALU 102 with $17 \mathrm{~mm}$. Significantly lower layer thickness can be seen in LALU 4 and LALU 2 with 12 and $6 \mathrm{~mm}$ respectively (Figs. 3, 4). The central areas show high sedimentation rates (columns LALU 13, 15, 102), where the cultural deposits were at the same time better protected due to dense pile positioning of the buildings and waterlogged conditions. Towards the south, west and east, lake level highs led to erosion of layers (profile LALU 2, 103). Higher areas towards the island in the north-east were more affected by dehydration and runoff. This area may well be regarded as semi-terrestrial, as the preservation of pollen was also comparatively worse (profile LALU 4; Heitz-Weniger 2014). A correlation of the layers fits well for the base of the sequences (Fig. 11). The natural lake marl shows signs of the lake regression and formation of an installation horizon. A sand layer covered a portion of the site. Above this an organic layer with signs of weathering has formed, which could indicate a short hiatus. From this point onwards the image becomes more heterogeneous, while towards the top several profiles indicate a less good preservation.

It is interesting to note that the sandy layers, regardless of what origin, divide the cultural layers into several intervals. By comparing the sequences of all the columns repetitive cycles could be recognised. Well preserved organic layers show in the upper parts signs of alteration and larger amounts of organic detritus. An accumulation of sand on the organic layer forms the top of the cycle. These successions could be recognised three to four times per column, in LALU 4 even six times (with the exception of profile LALU 2; Fig. 11). The reason of these cycles is most probably due to seasonal processes; during phases with a high groundwater table (from autumn to early summer) the remains accumulated fast and stayed well preserved. Sandy runoff sediments, as observed in the column LALU 4, can be related to melt water in late spring (Mitsch and Gosselink 2007). During mid-summer the groundwater table could drop due to elevated evaporation rates that led to the decay and soil formation processes in the desiccated part at the surface (Gastaldo and Demko 2011; Mitsch and Gosselink 2007). Sandy layers with strong signs of decay are the result of such a phase of 
Fig. 11 Simplified facies sequences of the profile columns (left hand side), an attempt to correlate the facies (middle part) and a possible scenario with seasonal accumulations during 6 years (right hand side)

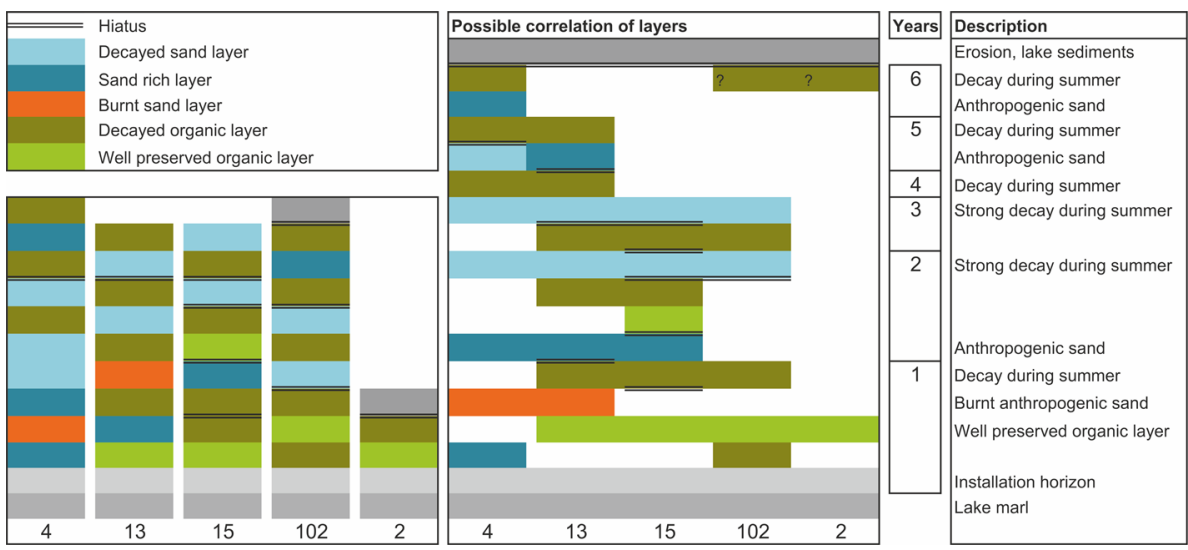

alteration. In autumn the groundwater level increased again and a new cycle started. If this interpretation is correct, then the resulting cultural layers would represent at most 6 years (number of sand inundations in the profile column LALU 4). The settlement period suggested by the dendrochronological dating is between 16 and 20 years (Bleicher 2014), so that one must assume that the cultural layer has not been preserved completely.

Finally, the history of L1 reflected in local environment data can be presented as follows. The area around Lake Luokesa was free of ice after around 14,000 cal BC (Guobyte and Satkūnas 2011). Lake marl began to be deposited in the riparian zones at the latest since the beginning of the Holocene around 10,000 cal BC. The highest water level in Lake Luokesa was most likely during the Atlantic period (Motuzaite Matuzevičiūte 2008; Kabailienè 2006; Menotti et al. 2005). During the beginning of the Subboreal, in around 3,300 cal BC, a mild climatic phase began and the water level dropped off to a level roughly 3-4 m below the current level (Pollmann 2014a). At around 750-250 cal BC (Sillasoo et al. 2009) a further warming can be postulated, which might have led to the formation of the lakeside platform in Lake Luokesa which was then settled at an unknown time between 625 and 535 cal BC (Bleicher 2014). Settlement activities led to the accumulation over several years of highly organic deposits that were sometimes exposed to desiccation during dry phases (midsummer?). Only after the abandonment of the site a transgression led to erosion of the topmost layers and covering with reworked lake marl. Whether this event is connected to a phase of falling temperatures and rising lake levels towards 150 cal BC (Sillasoo et al. 2009) cannot be answered. In recent times, growth of reed beds led to disturbance of some parts of the cultural deposits due to roots and rhizomes.

Comparison with some Neolithic lakeside settlements of the circum-alpine region show that site formation processes which led to accumulation, erosion and alteration of the deposits are largely the same as those reconstructed for the LBA/EIA site L1. Common features are also construction on water free carbonate platforms, no natural peat growth, fine laminations and sandy intercalations without limnic signs. Desiccation phases during summer were more pronounced at the Lithuanian site, which may be explained by the more continental climate. Some local features, such as topography and position of the site in relation to the lake (and its high stands), were of great importance for all the sites studied by us so far.

\section{Conclusions}

Due to a lake regression during the course of the LBA-EIA an extended lake marl peninsula was formed in Lake Luokesa. After drying of the riparian zone, between 625 and 535 cal BC, a settlement surrounded by double palisades was erected and inhabited for a period of up to 20 years (Bleicher 2014). As a result of this construction work an installation horizon, a trampled layer containing wood and bark residues from the preparation of the piles, was formed. During the existence of the settlement organic remains accumulated and remained well preserved due to a waterlogged environment, high accumulation rates and fast sealing. Manure layers show that domestic animals were at least temporarily kept in the settlement. Regularly appearing sand layers are the result of desiccation phases during mid-summer and inwash from the hinterland, indicating approximately 6 years of preserved data. After the abandonment of the settlement, the lake level rose, flooding the village, eroding part of the accumulations and overlaying the site with lake marl and sand. In later times, the lake seems never to have fallen below the level of the settlement, meaning that a further degrading of the organic material did not occur. Recent reeds have in some places disturbed the deposits with their roots and rhizomes.

With the interdisciplinary research at the LBA-EIA site L1 it was possible to combine archaeobotany (Pollmann 2014a), palynology (Heitz-Weniger 2014), dendrochronology (Bleicher 2014), archaeology (Pranckènaite 2014) 
and micromorphology. The detection of seasonal deposits was only possible due to a very close co-operation between these disciplines.

Further, it may be noted that the layer formation processes in the lakeside settlement L1 in the Baltic region seem to be very similar to those found in Switzerland. The topography of the hinterland and the location of the settlement in relation to the lake had a big influence in this context. These are important factors that determine whether cultural layer deposits are preserved or not.

Acknowledgments Many thanks to Elena Pranckenaitè and Vykintas Motuza for the numerous ideas, information and geological maps. Philippe Rentzel, Richard Macphailand and Matthew Canti also contributed with their knowledge. For the reviewing and support I want to thank Stefanie Jacomet, Urs Leuzinger, Małgorzata Latałowa and anonymous reviewers. Thanks also to Marlu Kühn, Petra Zibulski and Örni Akeret (IPAS), who helped in determining organic residues during the last 10 years. This evaluation is part of the project 'Understanding wetland occupation in late Prehistoric Europe' and has been facilitated and financed by the Swiss National Foundation (Project Number K13K1-117893).

\section{References}

Akeret Ö, Rentzel P (2001) Micromorphology and plant macrofossil analysis of cattle dung from the Neolithic lake shore settlement of Arbon Bleiche 3. Geoarchaeology 16:687-700

Babel U (1975) Micromorphology of soil organic matter. In: Gieseking JE (ed) Soil components, vol 1. Springer, Berlin, pp 369-473

Babel U (1985) Basic organic components. In: Bullock P, Fedoroff N, Jongerius A, Stoops G, Tursina T, Babel U (eds) Handbook for soil thin section description. Waine Research Publications, Wolverhampton, pp 50-73

Baker C, Thompson JR, Simpson M (2009) Hydrological dynamics I: surface waters, flood and sediment dynamics. In: Maltby E, Barker $\mathrm{T}$ (eds) The wetlands handbook. Wiley-Blackwell, Cichester, pp 120-168

Beckmann T (1997) Präparation bodenkundlicher Dünnschliffe für mikromorphologische Untersuchungen. In: Stahr K (ed) Mikromorphologische Methoden in der Bodenkunde. Hohenheimer Bodenkundliche Hefte 40, Hohenheim, pp 89-103

Bitinas A, Guobyte R, Grigiene A, Stancikaite M (1995) Report of the complex geological mapping, Vilnius

Bleicher N (2014) Dendrochronological analyses of wood samples from a Late Bronze-early Iron Age wetland site at Lake Luokesa in Lithuania. Veget Hist Archaeobot 23. doi:10.1007/s00334014-0463-1

Brochier JL (1983) L'habitat lacustre préhistorique: problèmes géologiques. Archiv des Sciences de Genève 36:247-260

Bullock P, Fedoroff N, Jongerius A, Stoops G, Tursina T, Babel U (1985) Handbook for soil thin section description. Waine Research Publication, Wolverhampton

Charman DJ (2009) Peat and Peatlands. In: Likens GE (ed) Encyclopedia of inland waters, vol 3. Elsevier Academic Press, Amsterdam, pp 507-610

Corfield M (2008) Wetland Science. In: Lillie M, Ellis S (eds) Wetland archaeology and environments: regional issues, global perspectives. Oxbow Books, Oxford, pp 143-155
Courty M-A, Goldberg P, Macphail R (1989) Soils and micromorphology in archaeology. Cambridge Manuals in Archaeology. Cambridge University Press, Cambridge

Cutler AH (1995) Taphonomic implications of shell surface textures in Bahia la Choya, northern Gulf of California. Palaeogeogr Palaeoclimatol Palaeoecol 114:219-240

Digerfeldt G, Sandgren P, Olsson S (2007) Reconstruction of Holocene lake-level changes in Lake Xinias, central Greece. Holocene 17:361-367

Fitzpatrick EA (1993) Soil microscopy and micromorphology. Wiley, Chichester

French CAI (2003) Geoarchaeology in action: studies in soil micromorphology and landscape evolution. Routledge, London

Freytet P, Verrecchia EP (2002) Lacustrine and palustrine carbonate petrography: an overview. J Paleolimnol 27:221-237

Gaigalas A, Dvareckas V (2002) The evolution of river valleys in Lithuania from deglaciation to recent changes and data from the sediment infill of oxbow lakes. Neth J Geosci/Geologie en Mijnbouw 81:407-416

Gastaldo RA, Demko TM (2011) The relationship between continental landscape evolution and the plant-fossil record: Long term hydrologic controls on preservation. In: Allison PA, Bottjer DJ (eds) Taphonomy: process and bias through time. Springer, Dordrecht, pp 249-285

Goldberg P, Macphail RI (2006) Practical and theoretical geoarchaeology. Blackwell, Oxford

Guobyte R, Satkūnas J (2011) Pleistocene glaciations in Lithuania. In: Ehlers J, Gibbard PL, Hughes PD (eds) Developments in quaternary science: quaternary glaciations-extent and chronology, a closer look, vol 15. Elsevier, Amsterdam, pp 231-246

Heitz-Weniger A (2014) Palynological investigations at the Late Bronze-early Iron Age lakeshore settlement of Luokesa 1 (Moletai District, Lithuania): a contribution to the Middle-Late Holocene vegetation history of the south-eastern Baltic regions. Veget Hist Archaeobot 23. doi:10.1007/s00334-014-0456-0

Holden J, Burt TP (2003) Hydrological studies on blanket peat: the significance of the acrotelm-catotelm model. J Ecol 91:86-102

Huber R, Ismail-Meyer K (2012) Cham-Eslen (Kanton Zug, Schweiz): ein jungneolithisches Haus mit (fast) allem Drum und Dran? Taphonomische Aspekte einer Seeufersiedlung. In: Link T, Schimmelpfennig D (eds) Taphonomische Forschungen (nicht nur) zum Neolithikum. Fokus Jungsteinzeit 3. Welt und Erde Verlag, Kerpen-Loogh, pp 83-106

Ismail-Meyer K (2010) Mikromorphologische Analyse zweier Profilkolonnen aus den Tauchsondagen von 1999 und 2007. In: Altorfer K (ed) Die prähistorischen Feuchtbodensiedlungen am Südrand des Pfäffikersees. Eine archäologische Bestandesaufnahme der Stationen Wetzikon-Robenhausen und Wetzikon-Himmerich. Monogr Kantonsarchäol Zürich 41, Zürich, pp 86-96

Ismail-Meyer K, Rentzel P (2004) Mikromorphologische Untersuchung der Schichtabfolge. In: Jacomet S, Leuzinger U, Schibler J (eds) Die jungsteinzeitliche Seeufersiedlung Arbon-Bleiche 3: Umwelt und Wirtschaft. Archäologie im Thurgau 12, Huber \& Co AG, Frauenfeld: Departement für Erziehung und Kultur des Kantons Thurgau, pp 66-80

Ismail-Meyer K, Rentzel P (in press) Paludal setting (wetland archaeology). In: Gilbert AS (ed) Encyclopedia of geoarchaeology. Encyclopedia of earth sciences series. Springer, New York

Ismail-Meyer K, Rentzel P, Wiemann P (2013) Neolithic lake-shore settlements in Switzerland: new insights on site formation processes from micromorphology. Geoarchaeology 28:317-339

Jacomet S, Leuzinger U, Schibler J (2004) Die jungsteinzeitliche Seeufersiedlung Arbon-Bleiche 3: Umwelt und Wirtschaft. Departement für Erziehung und Kultur des Kantons Thurgau, Archäologie im Thurgau 12, Huber \& Co AG, Frauenfeld 
Kabailienè M (2006) Main stages of natural environmental changes in Lithuania during the Late Glacial and Holocene. Geologija 55:37-47

Karkanas P, Goldberg P (2010) Phosphatic Features. In: Stoops G, Marcelino V, Mees F (eds) Interpretation of micromorphological features of soils and regoliths. Elsevier, Amsterdam, pp 521-541

Karkanas P, Pavlopoulos K, Kouli K, Ntinou M, Tsartsidou G, Facorellis Y, Tsourou T (2011) Palaeoenvironments and site formation processes at the Neolithic lakeside settlement of Dispilio, Kastoria, Northern Greece. Geoarchaeology 26:83-117

Kenward H, Hall A (2000) Decay of delicate organic remains in shallow urban deposits: are we at a watershed? Antiquity 74:519-525

Krier V (1997) Premières observations micromorphologiques sur la coupe de Chalain 3. In: Pétrequin P (ed) Chalain station 3, 3200-2900 av. J.-C., vol 1. Les sites littoraux néolithiques de Clairvaux-les-Lacs et de Chalain (Jura) 3. Maison des sciences de l'homme, Paris, pp 95-99

Lewis H (2007) Pile dwellings, drainage and deposition: preliminary soil micromorphology study of cultural deposits from underwater sites at Lake Luokesas, Moletai Region, Lithuania. J Wetland Archaeol 7:33-50

Lindsay R (2010) Peatbogs and carbon: a critical synthesis to inform policy development in oceanic peat bog conservation and restoration in the context of climate change. http://www.rspb. org.uk/Images/Peatbogs_and_carbon_tcm9-255200.pdf; https:// portals.iucn.org/2012forum/sites/2012forum/files/peatbogs-carboncritical-synthesis.pdf

Lyman RL (1994) Vertebrate taphonomy. Cambridge Manuals in Archaeology. Cambridge University Press, Cambridge

Macphail RI, Allen MJ, Crowther J, Cruise GM, Whittaker JE (2010) Marine inundation: effects on archaeological features, materials, sediments and soils. Quat Int 214:44-55

Magny M (1978) La dynamique des depots lacustres et les stations littorales du Grand Lac de Clairvaux (Jura). CNRS, Paris

Magny M (1992) Sédimentation et dynamique de comblement dans les lacs du Jura au cours des 15 dernières millenaires. Rev d'Archéometrie 16:27-49

Magny M (2004) Holocene climate variability as reflected by midEuropean lake-level fluctuations and its probable impact on prehistoric human settlements. Quat Int 113:65-79

Menotti F (2012) Wetland archaeology and beyond: theory and practice. Oxford University Press, Oxford

Menotti F, Baubonis Z, Brazaitis B, Higham T, Kvedaravicius M, Lewis H, Motuzaite G, Pranckenaite E (2005) The first lakedwellers of Lithuania: Late Bronze Age pile settlements on Lake Luokesas. Oxford J Archaeol 24:381-403

Mitsch WJ, Gosselink JG (2007) Wetlands. Wiley, Hoboken

Monnier J-L, Pétrequin P, Richard A, Pétrequin A-M, Gentizon A-L (1991) Construire une maison 3000 ans avant J.C.: Le lac de Chalain au Néolithique, vol 1. Archéologie de Franche-Comté, Edition Errance, Paris

Motuzaite Matuzevičiūte G (2008) Living above the water or on dry land? The application of soil analysis methods to investigate a submerged bronze age to early iron age lake dwelling site in eastern Lithuania. In: Girininkas A (ed) Archaeologia Baltica, vol 9. Klaipeda University Press, Klaipeda, pp 33-46

Novik A, Punning J-M, Zernitskayac V (2010) The development of Belarusian lakes during the Late Glacial and Holocene. Est J Earth Sci 59:63-79

Ostendorp W (1990) Zur Stratigraphie und Sediment-Petrographie der Station Allensbach—Strandbad: Profilsäule E6. Siedlungsarchäologie im Alpenvorland II, Forsch Ber Vor- Frühgesch Bad-Württ 37: 75-89

Ostendorp W (1996) Paläolimnologische Untersuchungen im Bereich der spätbronzezeitlichen Station Hagnau-Burg am Bodensee-
Obersee: Profiläule Ha 91-E1. Siedlungsarchäologie im Alpenvorland IV, Forsch Ber Vor- Frühgesch Bad-Württ 47:223-238

Pawluk S (1987) Faunal micromorphological features in moder humus of some western canadian soils. Geoderma 40:3-16

Platt NH, Wright VP (1991) Lacustrine carbonate: facies models, facies distribution and hydrocarbon aspects. Int Assoc Sedimentol 12:57-74

Pollmann B (2014a) Environment and agriculture of the transitional period from Late Bronze to early Iron Age in the Eastern Baltic: An archaeobotanical case study of the lakeshore settlement Luokesa 1 (Lithuania). Veget Hist Archaeobot 23. doi:10.1007/ s00334-014-0464-0

Pollmann B (2014b) Geschichte einer Feuchbodensiedlung um 600 v. Chr. am See Luokesa (Litauen): Rekonstruktion von Schichtgenese, Umwelt und Ernährung anhand archäobotanischer Analysen und taphonomischer Untersuchungen biologischer Makroreste. PhD thesis, University of Basel, Basel

Pranckènaite E (2014) Living in wetlands in the southeastern Baltic region during the Late Bronze to early Iron Age: the archaeological context of the Luokesa lake settlements. Veget Hist Archaeobot 23. doi:10.1007/s00334-014-0462-2

Punning J-M, Koff T, Kadastik E, Mikomägi A (2005) Holocene lake level fluctuations recorded in the sediment composition of Lake Juusa, southeastern Estonia. J Paleolimnol 34:377-390

Schiegl S, Goldberg P, Bar-Yosef O, Weiner S (1996) Ash deposits in Hayonim and Kebara caves, Israel: macroscopic, microscopic and mineralogical observations, and their archaeological implications. J Archaeol Sci 23:763-781

Sillasoo Ü, Poska A, Seppä H, Blaauw M, Chambers F (2009) Linking past cultural developments to palaeoenvironmental changes in Estonia. Veget Hist Archaeobot 18:315-327

Stančikaitè M, Kabailienè M, Ostrauskas T, Guobytė R (2002) Environment and man around Lakes Dūba and Pelesa, SE Lithuania, during the Late Glacial and Holocene. Geol Quat 46:391-409

Stančikaitė M, Kisielienè D, Strimaitienè A (2004) Vegetation response to the climatic and human impact changes during the post Glacial: case study of the marginal area of Baltija Upland, NE Lithuania. Baltica 17:17-33

Stolt MH, Lindbo DL (2010) Soil organic matter. In: Stoops G, Marcelino V, Mees F (eds) Interpretation of micromorphological features of soils and regoliths. Elsevier, Amsterdam, pp 368-396

Stoops G (2003) Guidelines for analysis and description of soil and regolith thin sections. Soil Science Society of America, Madison

Stoops G, Marcelino V, Mees F (2010) Interpretation of micromorphological features of soils and regoliths. Elsevier, Amsterdam

Takeda H (1988) A rapid method for preparing thin sections of soil organic layers. Geoderma 42:159-164

Turnbaugh WA (1978) Floods and archaeology. Am Antiq 43:593-607

van der Valk AG (2006) The biology of freshwater wetlands. The biology of habitats series. Oxford University Press, Oxford

Wallace G (1999) A microscopic view of Neolithic lakeside settlements on the northern rim of the European alps. Unpublished Thesis, University of Cambridge

Wallace G (2003) Using narrative to contextualise micromorphological data from Neolithic wetland houses. J Wetl Archaeol 3:75-92

Werner U, Reitner J (1989) Lebend- und Totengemeinschaften von Süsswassermollusken des Tegeler Sees - ein Beitrag zur Beurteilung seines ökologischen Zustandes. Berliner geowiss Abh, Reihe A 106:517-539

Zolitschka B, Behre K-E, Schneider J (2003) Human and climatic impact on the environment as derived from colluvial, flucial and lacustrine archives-examples from the Bronze Age to the Migration period, Germany. Quat Sci Rev 22:81-100 